\title{
RE-FEASIBILITY STUDY PENGEMBANGAN APARTEMEN CISAUK POINT DENGAN METODE SENSITIVITAS UNTUK OPTIMALISASI INVESTASI
}

\author{
Dodi $^{1)}$, Sylvie Wirawati ${ }^{2)}$, Irwan Wipranata ${ }^{3)}$ \\ 1)Program Studi S1 PWK, Fakultas Teknik, Universitas Tarumanagara, liem.dodi23@gmail.com \\ 2) Program Studi S1 PWK, Fakultas Teknik, Universitas Tarumanagara, sylview@ft.untar.ac.id \\ 3) Program Studi S1 PWK, Fakultas Teknik, Universitas Tarumanagara, irwan_wipranata@yahoo.co.uk
}

Masuk: 28-07-2021, revisi: 02-09-2021, diterima untuk diterbitkan: 23-10-2021

\begin{abstract}
Abstrak
Apartemen Cisauk Point merupakan bagian dan salah satu kawasan dari LRT City, yang menerapkan konsep TOD. Apartemen Cisauk Point berlokasi tepat di sisi Stasiun Cisauk, dimana Stasiun Cisauk sendiri melayani KRL Commuter Line dan terintegrasi dengan Intermoda BSD City. Dengan segala potensi yang dimiliki lahan pengembangan Cisauk Point, menarik bagi penulis untuk melakukan re-feasibility study atau studi kelayakan ulang terhadap pengembangan apartemen ini. Tujuan penelitian ini antara lain, yaitu mengetahui pengembalian investasi dari pengembangan Apartemen Cisauk Point setelah terhambat akibat pandemi COVID-19; dan mengetahui variabel-variabel yang mempengaruhi sensitivitas pengembalian investasi dari pengembangan Apartemen Cisauk Point. Re-feasibility study dilakukan untuk proyek-proyek yang telah menggunakan biaya atau sumber daya waktu yang lebih tinggi dari yang diharapkan, yang mengarah ke kekhawatiran atas validitas studi kelayakan asli. Tujuan re-feasibility study adalah untuk mencegah pemborosan anggaran dan untuk meningkatkan efisiensi pengelolaan keuangan dengan pengambilan keputusan yang transparan dan adil melalui investigasi yang objektif dan netral terhadap validitas proyek pengembangan properti. Analisis sensitivitas merupakan teknik dimana nilai yang berbeda dari variabel kunci tertentu adalah diuji untuk melihat seberapa sensitif hasil investasi terhadap kemungkinan perubahan asumsi. Optimalisasi investasi merupakan suatu tindakan atau proses untuk membuat investasi dari suatu proyek dapat menghasilkan pengembalian yang terbaik dan paling menguntungkan, serta investasi tersebut juga dapat menjadi lebih efektif dan efisien. Metode penelitian, menggunakan pendekatan kualitatif dengan metode discounted cash flow dan analisis sensitivitas. Penelitian menemukan bahwa investasi pengembangan Cisauk Point masih layak meski adanya Pandemi COVID-19, dan variabel yang paling berpengaruh kelayakan investasi adalah kenaikan harga jual.
\end{abstract}

Kata kunci: Cisauk Point; Investasi; Sensitivitas

\begin{abstract}
Cisauk Point Apartment is part and one of LRT City, which applies the TOD concept. Cisauk Point Apartment is located right next to Cisauk Station, where Cisauk Station itself serves KRL Commuter Line and integrates with Intermoda BSD City. With all the potential of the Cisauk Point Apartment, it is interesting for the author to conduct a re-feasibility study of this apartment's development. The objectives of this study include knowing the return on investment from the Cisauk Point Apartment's development after being hampered by the COVID-19 pandemic; and knowing the variables that affect the sensitivity of return on investment from the Cisauk Point Apartments development. Re-feasibility studies were conducted for projects that had used higher than expected costs or time resources, leading to concerns over the validity of the original feasibility studies. The purpose of the re-feasibility study is to prevent budget waste and to improve the efficiency of financial management by making transparent and fair decisions through objective and neutral investigations of the validity of property development projects. Sensitivity analysis is a technique in which different values of certain key variables are tested to see how sensitive the investment returns are to possible changes in assumptions. Investment optimization is an action or process to make the investment of a project produce the best and most profitable returns, and the investment can also be more effective and efficient. The research method uses a qualitative approach with discounted cash flow methods and sensitivity analysis. The study found that the investment in Cisauk Point development was still feasible despite the COVID-19 pandemic, and the most influential variable on investment feasibility was the increase in selling prices.
\end{abstract}

Keywords: Cisauk Point; Investment; Sensitivity 


\section{PENDAHULUAN}

\section{Latar Belakang}

Jabodetabek telah berkembang menjadi wilayah megapolitan, karena jumlah penduduk total dari wilayah ini telah mencapai angka 30 juta penduduk. Jakarta sebagai sentral dari Jabodetabek, memiliki kebutuhan hunian yang tinggi dan mencapai 100.000 unit hunian per tahunnya. Namun, pasokan hunian yang ada belum dapat memenuhi kebutuhan yang ada, karena keterbatasan lahan di Jakarta dan tingginya harga lahan jika dikembangkan untuk hunian.

Hal tersebut mengakibatkan banyak penduduk yang bekerja di Jakarta tidak dapat memiliki hunian di Ibu Kota, sehingga lebih memilih untuk tinggal di kota satelit Jakarta, seperti Bogor, Depok, Tangerang dan juga Bekasi. Oleh karena itu, para penduduk tersebut memiliki pilihan untuk melakukan perjalanan menuju lokasi kerja dengan kendaraan pribadi atau transportasi massal, yang dilakukan setiap hari kerja sehingga aktivitas tersebut disebut commuting.

Dengan banyaknya penduduk luar Jakarta yang berkendara dengan kendaraan pribadi, mengakibatkan kemacetan yang semakin parah di Jakarta. Hal tersebut juga menyebabkan transportasi massal mulai dilirik oleh para commuter. Dan untuk mengakomodir kebutuhan para commuter tersebut, muncul konsep pengembangan berorientasi terhadap transportasi massal. Konsep pengembangan tersebut adalah Transit Oriented Development atau yang sering disebut TOD.

Banyak pengembangan TOD yang mulai berkembang baik di Jakarta maupun di luar Jakarta, dan salah satunya adalah LRT City. LRT City merupakan pengembangan kawasan TOD yang terintegrasi dengan sistem transportasi massal seperti LRT, KRL, dan juga bus. Beberapa kawasan yang sedang dikembangkan LRT City antara lain Royal Sentul Park, Eastern Green, Gateway Park, dan juga Cisauk Point. Namun pandemi COVID-19 sangat berdampak pada properti, karena terdapat banyak pengembangan properti mengalami hambatan baik tahap konstruksi ataupun tahap penjualan, tidak terkecuali proyek LRT City.

Cisauk Point merupakan bagian dan salah satu kawasan dari LRT City, yang menerapkan konsep TOD yang terintegrasi dengan sistem transportasi massal yang bersifat multimoda, yaitu KRL dan juga bus. Cisauk Point terletak di Desa Cibogo, Kecamatan Cisauk, Kabupaten Tangerang, dan berlokasi tepat di sisi Stasiun Cisauk dan Terminal Bus Cisauk. Dimana Stasiun Cisauk sendiri melayani KRL Commuter Line rute perjalanan Tanah Abang - Rangkasbitung, dengan 132 perjalanan KRL per harinya.

Cisauk Point berlokasi di kawasan yang terbilang strategis, karena dekat dengan beberapa kawasan kota mandiri seperti BSD City, Alam Sutera, dan juga Gading Serpong. Karena letaknya yang bersebelahan dengan Stasiun Cisauk, mengkondisikan Cisauk Point juga terintegrasi dengan kawasan Intermoda BSD City. Selain itu, kawasan Cisauk juga merupakan kawasan yang akan dilewati Jalan Tol Serpong - Balaraja, yang direncanakan rampung dibangun pada tahun 2024, dengan total ruas tol sepanjang $39,8 \mathrm{~km}$.

Dengan segala potensi yang dimiliki lahan pengembangan Cisauk Point, menarik bagi penulis untuk melakukan re-feasibility study atau studi kelayakan ulang terhadap pengembangan apartemen ini. Refeasibility study ini dilakukan untuk merelevansi studi kelayakan yang telah dibuat sebelumnya yaitu pada tahun 2018. Dengan demikian, penulis dapat memberikan rekomendasi bagi developer dalam merealisasikan pengembangan apartemen tersebut.

\section{Rumusan Permasalahan}

Rumusan permasalahan dalam penelitian ini adalah sebagai berikut.

1) Studi kelayakan Apartemen Cisauk Point yang telah disusun jauh sebelum pandemi COVID-19, sehingga perlu dievaluasi relevansinya di kondisi saat ini yaitu di tengah pandemi COVID-19,

2) Permintaan dan daya beli masyarakat terhadap properti yang menurun karena krisis ekonomi akibat pandemi COVID-19, 
3) Pengembangan Apartemen Cisauk Point yang sempat terhambat, baik tahap konstruksi maupun tahap penjualan, akibat pandemi COVID-19.

\section{Tujuan}

Tujuan dari penelitian ini adalah sebagai berikut.

1) Mengetahui dampak pandemi COVID-19 terhadap pengembangan Apartemen Cisauk Point,

2) Mengetahui pengembalian investasi dari pengembangan Apartemen Cisauk Point setelah terhambat akibat pandemi COVID-19,

3) Mengetahui variabel-variabel yang mempengaruhi sensitivitas pengembalian investasi dari pengembangan Apartemen Cisauk Point,

4) Mengetahui besaran sensitivitas dan korelasi antar variabel dalam analisis sensitivitas pada Apartemen Cisauk Point.

\section{KAJIAN LITERATUR}

\section{Pengembangan Real Estate}

Pengembangan real estate adalah proses mewujudkan ruang yang dibangun untuk membuahkan hasil. Ini dimulai dengan sebuah ide dan berakhir ketika konsumen (penyewa) atau pemilik (penghuni) menempati fisiknya ruang yang disiapkan oleh tim pengembangan. Setiap proyek real estate pada intinya adalah entitas bisnis terpisah yang menggunakan tiga faktor produksi yaitu tanah, tenaga kerja, dan modal untuk membuat produk.

Untuk mengubah ide menjadi kenyataan, faktor-faktor ini adalah dikoordinasikan oleh manajemen kewirausahaan dan disampaikan oleh tim. Nilai diciptakan oleh menyediakan ruang untuk memenuhi kebutuhan masyarakat. Meskipun definisi real estate pengembangan tetap sederhana, proses tumbuh semakin kompleks seperti kota, pasar keuangan, dan selera konsumen berkembang. (E. Miles, 2015)

\section{Re-Feasibility Study}

Re-feasibility study dilakukan untuk proyek-proyek yang telah menggunakan biaya atau sumber daya waktu yang lebih tinggi dari yang diharapkan, yang mengarah ke kekhawatiran atas validitas studi kelayakan asli. Meskipun re-feasibility study umumnya dimulai untuk proyek yang sedang dalam tahap pelaksanaan, ada beberapa contoh ketika re-feasibility study dapat dilakukan selama tahap persiapan juga (terutama karena penundaan antara penyelesaian feasibility study/studi kelayakan dan persetujuan proyek).

Tujuan re-feasibility study adalah untuk mencegah pemborosan anggaran dan untuk meningkatkan efisiensi pengelolaan keuangan dengan pengambilan keputusan yang transparan dan adil melalui investigasi yang objektif dan netral terhadap validitas proyek pengembangan properti.

\section{Investasi}

Secara umum, investasi merupakan penanaman modal untuk mendapatkan pendapatan di masa yang akan datang. Pada real estate, investasi dapat diartikan sebagai suatu kegiatan penanaman modal pada hak-hak atas tanah dan bangunan secara produktif.

Dengan membandingkan nilai investasi yang akan ditanamkan dengan tingkat pengembalian yang diharapkan, maka kegiatan investasi memerlukan beberapa kriteria untuk menentukan keputusan investasi. Metode yang akan digunakan dalam pembahasan penelitian ini adalah metode Discounted Cash Flow Model yang disebut present value, yang menekankan pada pendapatan yang dihasilkan setelah dipotong pajak dalam bentuk cash flow.

\section{Optimalisasi Investasi}

Menurut KBBI, optimalisasi adalah berasal dari kata dasar optimal yang berarti terbaik, tertinggi, paling menguntungkan, menjadikan paling baik, menjadikan paling tinggi, pengoptimalan proses, cara, perbuatan mengoptimalkan (menjadikan paling baik, paling tinggi, dan sebagainya). Sehingga, optimalisasi adalah suatu tindakan, proses, atau metodologi untuk membuat sesuatu (sebagai sebuah 
desain, sistem, atau keputusan) menjadi lebih/sepenuhnya sempurna, fungsional, atau lebih efektif. Dengan demikan, optimalisasi investasi merupakan suatu tindakan atau proses untuk membuat investasi dari suatu proyek dapat menghasilkan pengembalian yang terbaik dan paling menguntungkan, serta investasi tersebut juga dapat menjadi lebih efektif dan efisien.

\section{Analisis Sensitivitas}

Salah satu cara untuk mendapatkan gambaran tentang semua kemungkinan hasil dari suatu investasi adalah dengan melakukan analisis sensitivitas, teknik dimana nilai yang berbeda dari variabel kunci tertentu adalah diuji untuk melihat seberapa sensitif hasil investasi terhadap kemungkinan perubahan asumsi. Analisis sensitivitas adalah metode untuk menilai risiko suatu investasi. Dalam menghitung arus kas, beberapa item memiliki pengaruh lebih pada hasil akhir daripada yang lain. Dalam beberapa masalah, item yang paling signifikan mudah diidentifikasi. Misalnya, perkiraan volume penjualan dapat memiliki dampak besar dalam pengembalian investasi proyek. (Chan, 2013)

Analisis sensitivitas merupakan salah satu cara paling mudah untuk menganalisis risiko pada investasi properti. Ini melibatkan mengubah satu atau lebih asumsi utama yang tidak pasti untuk melihat seberapa sensitif investasi kinerja properti adalah untuk perubahan asumsi itu. Asumsi itu biasanya diperiksa dalam analisis sensitivitas termasuk harga sewa pasar yang diharapkan, lowongan tarif, biaya operasional, dan harga jual kembali yang diharapkan. Analisis sensitivitas dimulai dengan kasus dasar, yaitu sekumpulan asumsi yang akan dianalisis yang akan memberikan kerangka acuan untuk analisis sensitivitas. Kumpulan asumsi ini biasanya mewakili perkiraan terbaik analis dari situasi yang paling mungkin.

Setelah kumpulan asumsi kasus dasar telah diidentifikasi, analis menghitung IRR, NPV, dan ukuran kinerja investasi lainnya menggunakan kumpulan asumsi dasar ini. Kemudian analis memvariasikan asumsi satu atau lebih pada satu waktu untuk melihat bagaimana setiap perubahan mempengaruhi hasil. Biasanya pendekatan untuk mengubah asumsi adalah mengubah satu asumsi sekaligus atau untuk mengidentifikasi beberapa skenario di mana lebih dari satu variabel perubahan dalam skenario tertentu.

\section{METODE}

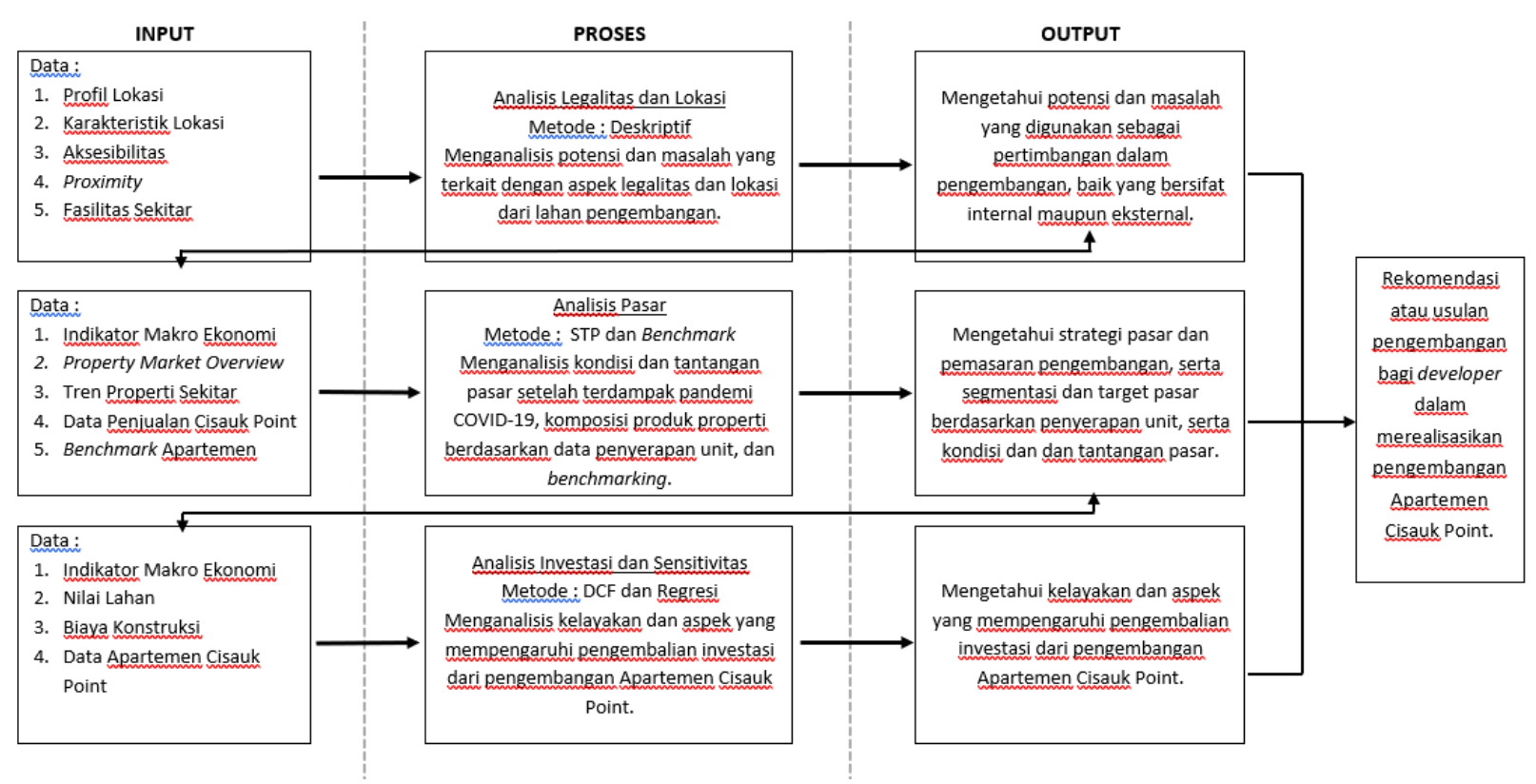




\section{DISKUSI DAN HASIL Profil Objek Studi}

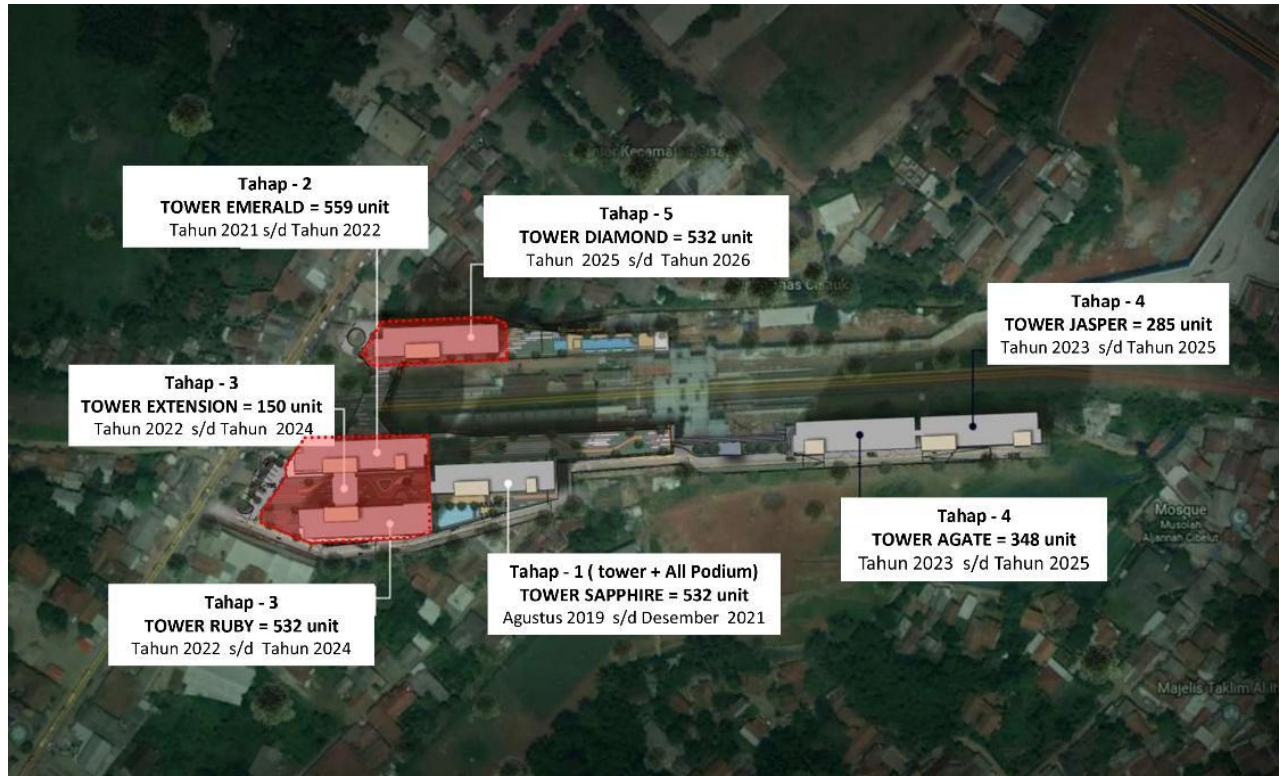

Gambar 1. Master Plan \& Tahap Pengembangan Apartemen Cisauk Point Sumber: Cisauk Point, 2020

Cisauk Point berlokasi di Jl. Raya Cisauk, Cibogo, Kec. Cisauk, Kab. Tangerang, dengan luas lahan sebesar $16.500 \mathrm{~m} 2$. Cisauk Point merupakan produk hasil kolaborasi antara PT Adhi Commuter Properti (ACP), anak usaha BUMN dari PT Adhi Karya (Persero) Tbk dengan PT Kereta Api Indonesia (Persero). Proyek pengembangan Cisauk Point telah dimulai pada Agustus 2019, dan pengembangan keseluruhan kawasan direncanakan akan rampung pada tahun 2026.

Cisauk Point merupakan sebuah kawasan yang direncanakan terdiri dari enam tower hunian, yang terbagi atas empat tower apartemen, dan dua tower rusunami. Namun, lingkup dalam penelitian ini adalah tiga tower Apartemen Cisauk Point, yaitu Tower Emerald, Ruby, dan Diamond yang merupakan tahap 2, 3, dan 5 dari pengembangan kawasan Cisauk Point. Berikut merupakan visual dari Apartemen Cisauk Point.

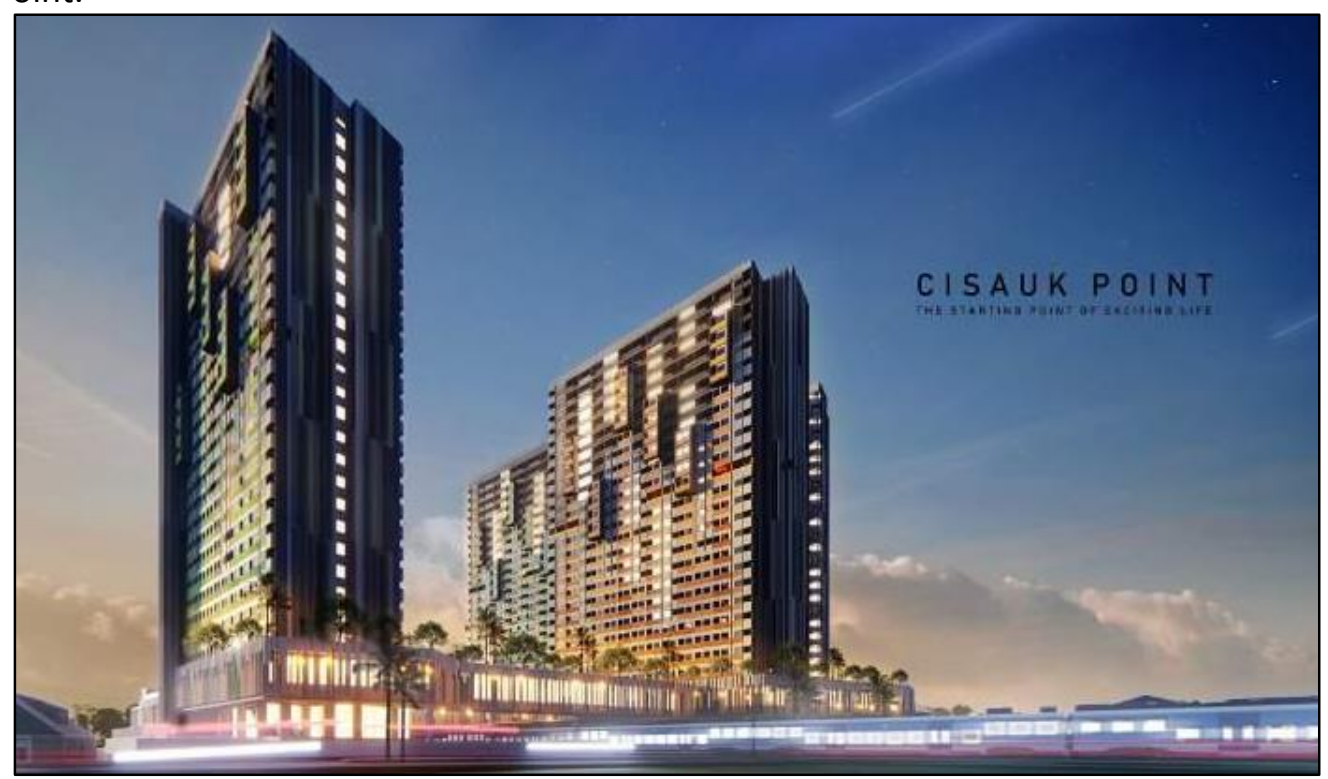

Gambar 2. Visual Apartemen Cisauk Point

Sumber: Cisauk Point, 2020 
Tabel 1. Informasi Kawasan \& Bangunan Apartemen Cisauk Point

\begin{tabular}{|c|c|c|c|c|c|}
\hline No. & Tower & Jumlah Unit & $\begin{array}{l}\text { Jumlah } \\
\text { Lantai }\end{array}$ & $\begin{array}{c}\text { Luas per } \\
\text { Lantai }\left(\mathrm{m}^{2}\right)\end{array}$ & $\begin{array}{c}\text { Luas Total } \\
\text { Bangunan }\left(\mathrm{m}^{2}\right)\end{array}$ \\
\hline \multicolumn{6}{|c|}{ Apartemen } \\
\hline 1 & Emerald & 559 & 26 & 669,7 & 17.480 \\
\hline 2 & Ruby + Extension & $532+150$ & 26 & 842,7 & 22.027 \\
\hline \multirow[t]{2}{*}{3} & Diamond & 532 & 26 & 673,8 & 17.646 \\
\hline & Sub Total & 1.773 & & & 57.153 \\
\hline \multicolumn{6}{|c|}{ Komersial } \\
\hline 1 & Emerald & & \multirow{2}{*}{5} & \multirow{2}{*}{1.810} & \multirow{2}{*}{18.100} \\
\hline 2 & Ruby + Extension & & & & \\
\hline \multirow[t]{3}{*}{3} & Diamond & & 4 & 1.195 & 4.780 \\
\hline & Sub Total & & & & 22.880 \\
\hline & Total & & & & 80.033 \\
\hline
\end{tabular}

Berdasarkan tabel rencana pengembangan di atas, ketiga tower apartemen memiliki jumlah lantai sebanyak 26 lantai, dengan luas total bangunan sebesar $57.152 \mathrm{~m}^{2}$. Sedangkan untuk commercial area yang akan dikembangkan akan menjadi podium dari apartemen tersebut dengan jumlah lantai sebanyak 4-5 lantai, dengan luas total bangunan sebesar $22.880 \mathrm{~m}^{2}$. Dengan demikian dapat diketahui total luas bangunan dari rencana pengembangan Cisauk Point, yaitu seluas $80.033 \mathrm{~m}^{2}$.

Tabel 2. Informasi Produk Apartemen Cisauk Point

\begin{tabular}{|c|c|c|c|c|c|c|}
\hline No. & Tipe Unit & Jumlah Unit & Luas Unit (m2) & & Harga Jual & Harga Jual/m2 \\
\hline I & Tower Emerald & & & & & \\
\hline 1 & Studio 1 & 375 & 24,40 & $\mathrm{Rp}$ & 362.350 .000 & Rp 14.850 .410 \\
\hline 2 & Studio 2 & 25 & 25,30 & $\mathrm{Rp}$ & 375.700 .000 & Rp 14.849 .802 \\
\hline 3 & Studio 3 & 22 & 26,90 & $\mathrm{Rp}$ & 399.500 .000 & Rp 14.851 .301 \\
\hline 4 & Studio+ & 30 & 29,00 & $\mathrm{Rp}$ & 430.650 .000 & Rp 14.850 .000 \\
\hline 5 & Studio 3+ & 4 & 32,75 & $\mathrm{Rp}$ & 486.340 .000 & Rp 14.850 .076 \\
\hline 6 & $1 \mathrm{BR}$ & 25 & 38,00 & $\mathrm{Rp}$ & 564.300 .000 & Rp 14.850 .000 \\
\hline 7 & $1 \mathrm{BR} 1 \mathrm{~A}$ & 25 & 38,50 & $\mathrm{Rp}$ & 571.725 .000 & Rp 14.850 .000 \\
\hline \multirow[t]{2}{*}{8} & $1 \mathrm{BR} 2$ & 26 & 35,00 & $\mathrm{Rp}$ & 519.750 .000 & Rp 14.850 .000 \\
\hline & Total & 532 & & & & \\
\hline II & Tower Ruby & & & & & \\
\hline 1 & Studio 1 & 405 & 24,40 & $\mathrm{Rp}$ & 362.350 .000 & Rp 14.850 .410 \\
\hline 2 & Studio 2 & 25 & 25,30 & $\mathrm{Rp}$ & 375.700 .000 & Rp 14.849 .802 \\
\hline 3 & Studio 3 & 26 & 26,90 & $\mathrm{Rp}$ & 399.500 .000 & Rp 14.851 .301 \\
\hline 4 & Studio+ & 26 & 29,00 & $\mathrm{Rp}$ & 430.650 .000 & Rp 14.850 .000 \\
\hline 5 & $1 \mathrm{BR}$ & 25 & 38,00 & $\mathrm{Rp}$ & 564.300 .000 & Rp 14.850 .000 \\
\hline 6 & $1 \mathrm{BR} 1 \mathrm{~A}$ & 26 & 38,50 & $\mathrm{Rp}$ & 571.725 .000 & Rp 14.850 .000 \\
\hline \multirow[t]{2}{*}{7} & $1 \mathrm{BR} 2$ & 26 & 35,00 & $\mathrm{Rp}$ & 519.750 .000 & Rp 14.850 .000 \\
\hline & Total & 559 & & & & \\
\hline III & \multicolumn{6}{|c|}{ Tower Ruby Extension } \\
\hline 1 & Studio 1 & 50 & 24,40 & $\mathrm{Rp}$ & 362.350 .000 & Rp 14.850 .410 \\
\hline \multirow[t]{2}{*}{2} & Studio 3 & 100 & 26,90 & $\mathrm{Rp}$ & 399.500 .000 & Rp 14.851 .301 \\
\hline & Total & 150 & & & & \\
\hline IV & Tower Diamond & & & & & \\
\hline 1 & Studio 1 & 374 & 24,40 & $\mathrm{Rp}$ & 362.350 .000 & Rp 14.850 .410 \\
\hline 2 & Studio 2 & 25 & 25,30 & $\mathrm{Rp}$ & 375.700 .000 & Rp 14.849 .802 \\
\hline 3 & Studio 3 & 26 & 26,90 & $\mathrm{Rp}$ & 399.500 .000 & Rp 14.851 .301 \\
\hline 4 & Studio+ & 30 & 29,00 & $\mathrm{Rp}$ & 430.650 .000 & Rp 14.850 .000 \\
\hline \multirow[t]{2}{*}{5} & $1 \mathrm{BR} 2$ & 77 & 35,00 & $\mathrm{Rp}$ & 519.750 .000 & Rp 14.850 .000 \\
\hline & Total & 532 & & & & \\
\hline
\end{tabular}

Sumber: Cisauk Point, 2020 
Berdasarkan tabel informasi produk apartemen di atas, dapat diketahui bahwa terdapat 2 tipe unit yang ditawarkan oleh Cisauk Point, yaitu studio, 1 BR. Namun dari kedua tipe dasar tersebut, dibagi menjadi 8 tipe unit dengan luas unit yang beragam meskipun tidak berbeda signifikan. Harga unit yang ditawarkan pun beragam, mulai dari unit dengan harga terendah yaitu Rp 362.350 .000 , hingga unit dengan harga tertinggi yaitu $\mathrm{Rp}$ 571.725.000.

\section{Analisis Investasi}

Pada project investment, akan dilakukan perhitungan mengenai besaran biaya yang dikeluarkan dalam investasi pengembangan Cisauk Point. Biaya tersebut akan dikategorikan ke dalam 6 kategori biaya pengembangan. Berikut merupakan tabel project investment dari Cisauk Point.

Tabel 3. Total Project Investment Apartemen Cisauk Point

\begin{tabular}{clclc}
\hline No. & & Total Investment Cost & & Persentase \\
\hline 1 & Land Cost & 1.900 .000 .000 & Rupiah & $0,25 \%$ \\
\hline 2 & Construction Cost & 660.282 .637 .338 & Rupiah & $88,41 \%$ \\
\hline 3 & Legal and Permit Fees & 14.526 .218 .021 & Rupiah & $1,94 \%$ \\
\hline 4 & Professional Fees & 23.109 .892 .307 & Rupiah & $3,09 \%$ \\
\hline 5 & Operational Expenses & 39.616 .958 .240 & Rupiah & $5,30 \%$ \\
\hline 6 & $\begin{array}{l}\text { Infrastructure \& } \\
\text { Facilities Cost }\end{array}$ & $\mathbf{7 . 6 7 5 . 0 0 0 . 0 0 0}$ & Rupiah & $1,00 \%$ \\
\hline & Total & $\mathbf{7 4 7 . 1 1 0 . 7 0 5 . 9 0 7}$ & Total & $\mathbf{1 0 0 , 0 0 \%}$ \\
\hline INVESTMENT COST PER SQM & $\mathbf{9 . 2 8 0 . 8 7 8}$ & $\begin{array}{c}\text { TOTAL BUILDING } \\
\text { COV. }\end{array}$ & $\mathbf{8 0 . 5 0 0}$ \\
\hline
\end{tabular}

Sumber: Olahan Penulis, 2021

Berdasarkan tabel total project investment di atas, dapat diketahui bahwa biaya pengembangan terbesar adalah biaya konstruksi yaitu sebesar Rp 660.282 .637 .338 atau $88,41 \%$ dari total biaya pengembangan yang berjumlah Rp 747.110.705.907. Selain itu, didapatkan juga biaya investasi per $\mathrm{m} 2$ yaitu sebesar Rp 9.280.878.

Berikut merupakan cash flow dari Apartemen Cisauk Point. Dimana cash flow tersebut terbagi atas penerimaan atau cash in, pengeluaran atau cash out. Untuk penerimaan atau cash in, karena pada Apartemen Cisauk Point juga terdapat commercial area, sehingga penerimaan yang didapatkan oleh Apartemen Cisauk Point berasal dari apartemen dan juga commercial area tersebut. Berikut merupakan rincian dari cash in Apartemen Cisauk Point.

Tabel 4. Total Cash In Project Apartemen Cisauk Point

\begin{tabular}{clc}
\hline \multicolumn{1}{c}{ No. } & \multicolumn{1}{c}{ Keterangan } & Total \\
\hline A & Apartemen & 119.415 .192 .824 \\
\hline 1 & Penerimaan Penjualan Hard Cash & 734.204 .410 .548 \\
\hline 2 & Penerimaan Penjualan KPA & 217.798 .433 .489 \\
\hline 3 & Penerimaan Service Charge & $\mathbf{1 . 0 7 1 . 4 1 8 . 0 3 6 . 8 6 1}$ \\
\hline \multicolumn{3}{c}{ Total Cash In Apartemen } \\
\hline & Commercial Area & 774.463 .954 .682 \\
\hline 2 & Penerimaan Sewa & $\mathbf{2 2 1 . 2 7 5 . 4 1 5 . 6 2 3}$ \\
\hline 3 & Penerimaan Service Charge & 15.488 .135 .520 \\
\hline & Total Cash In Commercial Area & $\mathbf{1 . 0 1 1 . 2 2 7 . 5 0 5 . 8 2 5}$ \\
\hline & Total Cash In Project & $\mathbf{2 . 0 8 2 . 6 4 5 . 5 4 2 . 6 8 6}$ \\
\hline
\end{tabular}

Sumber: Olahan Penulis, 2021 
Berdasarkan tabel di atas, dapat diketahui bahwa total penerimaan atau cash in yang diterima oleh Apartemen Cisauk Point yaitu sebesar Rp 2.082.645.542.686,-. Total cash in tersebut terbagi atas dua penerimaan, yaitu apartemen dan commercial area, dengan total penerimaan masing-masing adalah Rp 1.071.418.036.861,- dan Rp 1.011.227.505.825,-. Untuk pengeluaran atau cash out, terbagi atas dua yaitu investment cost dan development expenses. Dimana untuk development expenses juga terbagi atas apartemen dan commercial area. Berikut merupakan rincian dari cash out Apartemen Cisauk Point.

Tabel 5. Total Cash Out Project Apartemen Cisauk Point (dalam jutaan rupiah)

\begin{tabular}{|c|c|c|}
\hline No. & Keterangan & Total \\
\hline \multicolumn{3}{|c|}{ INVESTMENT COST } \\
\hline A & Hard Cost & \\
\hline 1 & Land Cost & 1.900 \\
\hline 2 & Construction Cost & 660.283 \\
\hline 3 & Legal and Permit Fees & 14.526 \\
\hline 4 & Professional Fees & 23.110 \\
\hline 5 & Infrastructure \& Facilities Cost & 7.675 \\
\hline \multicolumn{2}{|r|}{ Total Hard Cost } & 707.494 \\
\hline B & Soft Cost & \\
\hline 1 & Operational Expense & 39.617 \\
\hline \multicolumn{2}{|r|}{ Total Soft Cost } & 39.617 \\
\hline \multicolumn{3}{|c|}{ DEVELOPMENT EXPENSES } \\
\hline 1 & Apartemen & 333.144 \\
\hline 2 & Commercial Area & 253.480 \\
\hline \multicolumn{2}{|r|}{ Total Development Expenses } & 586.624 \\
\hline \multicolumn{2}{|r|}{ Total Cash Out Project } & 1.333.735 \\
\hline
\end{tabular}

Sumber: Olahan Penulis, 2021

Berdasarkan tabel di atas, dapat diketahui bahwa total pengeluaran atau cash out Apartemen Cisauk Point yaitu sebesar Rp 1.333.735.000.000,-. Total cash out tersebut terbagi atas dua pengeluaran, yaitu investment cost dan development expenses, dengan total pengeluaran masing-masing adalah Rp 707.494.000.000,- dan Rp 586.624.000.000,-.

Setelah mengetahui keseluruhan penerimaan dan juga pengeluaran dari Cisauk Point, yang terdiri dari apartemen dan commercial area, dapat dihitung cash flow dari dari Cisauk Point. Dari cash flow tersebut dapat diketahui bagaimana kelayakan investasi dari Cisauk Point. Kelayakan investasi tersebut dinilai dari beberapa indikator kelayakan investasi, dan berikut adalah tabel tersebut.

Tabel 6. Indikator Kelayakan Investasi Apartemen Cisauk Point

\begin{tabular}{clccc}
\hline No. & \multicolumn{1}{c}{ Indikator } & Nilai & Satuan & Keterangan \\
\hline 1 & Tingkat Suku Bunga & $11,00 \%$ & - & - \\
\hline 2 & IRR & $17,40 \%$ & - & >Suku Bunga (Layak) \\
\hline 3 & NPV & 73.558 & Juta Rupiah & $>$ Rp 1 (Layak) \\
\hline 4 & PP & 6,97 & Tahun & - \\
\hline 5 & PI & 1,13 & - & $>1$ (Layak) \\
\hline 6 & ROI & $56,15 \%$ & - & $>0$ (Layak) \\
\hline 7 & Cash In & 2.082 .646 & Juta Rupiah & - \\
\hline 8 & Cash Out & 1.333 .735 & Juta Rupiah & - \\
\hline 9 & Net Cash Flow & 748.911 & Juta Rupiah & - \\
\hline Sumber: Olahan Penulis, 2021 & & &
\end{tabular}

Sumber: Olahan Penulis, 2021 
Berdasarkan tabel kelayakan investasi di atas, dapat diketahui bahwa keempat indikator kelayakan investasi yang ada menunjukkan angka yang positif, dimana mengartikan bahwa investasi pengembangan Cisauk Point adalah investasi yang layak. Indikator kelayakan investasi yang pertama adalah IRR, hasil IRR dari cash flow yang ada adalah sebesar $17,4 \%$, dimana angka tersebut lebih besar dari suku bunga yang digunakan yaitu $11 \%$, yang berarti investasi tersebut layak.

Untuk NPV, hasilnya juga menunjukkan angka yang positif yaitu Rp 73.558.000.000, dimana angka tersebut lebih besar dari Rp 1, sehingga investasi tersebut juga dapat dinyatakan layak. Sedangkan untuk PI, hasilnya adalah 1,13 yang berarti investasi tersebut layak, karena angka tersebut lebih besar dari 1. Selain itu, indikator kelayakan investasi yang terakhir adalah ROI, dan hasilnya sebesar $56,15 \%$ yang berarti investasi tersebut juga layak, karena lebih besar dari 0.

Tidak hanya indikator kelayakan investasi yang telah dijelaskan di atas, tetapi juga diketahui beberapa indikator lainnya yang dapat menggambarkan investasi tersebut. Indikator tersebut adalah PP, dimana memiliki hasil 6,97 tahun, yang berarti investasi dari Cisauk Point memerlukan waktu selama 6,97 tahun untuk dapat menerima pengembalian investasinya.

\section{Analisis Sensitivitas}

Dalam analisis sensitivitas ini, akan dilakukan sebuah analisis yang bertujuan untuk mengetahui sensitivitas dari indikator kelayakan keuangan, yaitu IRR dan NPV, terhadap beberapa variabel pengembangan. Variabel tersebut antara lain adalah suku bunga, kenaikan biaya konstruksi, take-up rate, dan kenaikan harga jual. Keempat variabel tersebut akan diuji dengan masing-masing indikator kelayakan investasi, yaitu IRR dan NPV.

Selain itu, keempat variabel tersebut juga dikelompokkan menjadi 2, yaitu yang berkaitan dengan pengeluaran (cash out), dan penerimaan (cash in). Variabel yang berkaitan dengan pengeluaran (cash out) adalah suku bunga dan kenaikan biaya konstruksi. Sedangkan, variabel yang berkaitan dengan penerimaan (cash in) adalah take-up rate dan kenaikan harga jual.

Dari masing-masing variabel tersebut dibagi menjadi 3 skenario, yaitu optimis, moderat, dan juga pesimis. Dimana pada setiap skenario tersebut terdiri atas 2 besaran angka atau persentase, yang disesuaikan besaran angkanya dengan kondisi normal dan juga kondisi Pandemi Covid-19. Besaran angka tersebut juga memiliki selisih angka yang tidak terlalu jauh pada setiap skenarionya. Hal tersebut bertujuan untuk lebih menunjukkan tingkat kepekaan pada sensitivitas dari IRR dan NPV.

\section{Sensitivitas IRR terhadap Suku Bunga dan Kenaikan Biaya Konstruksi}

Sensitivitas IRR akan diuji dengan 2 variabel yang berkaitan dengan pengeluaran (cash out), yaitu suku bunga dan kenaikan biaya konstruksi, dan berikut adalah tabel tersebut.

Tabel 7. Sensitivitas IRR terhadap Suku Bunga dan Kenaikan Biaya Konstruksi

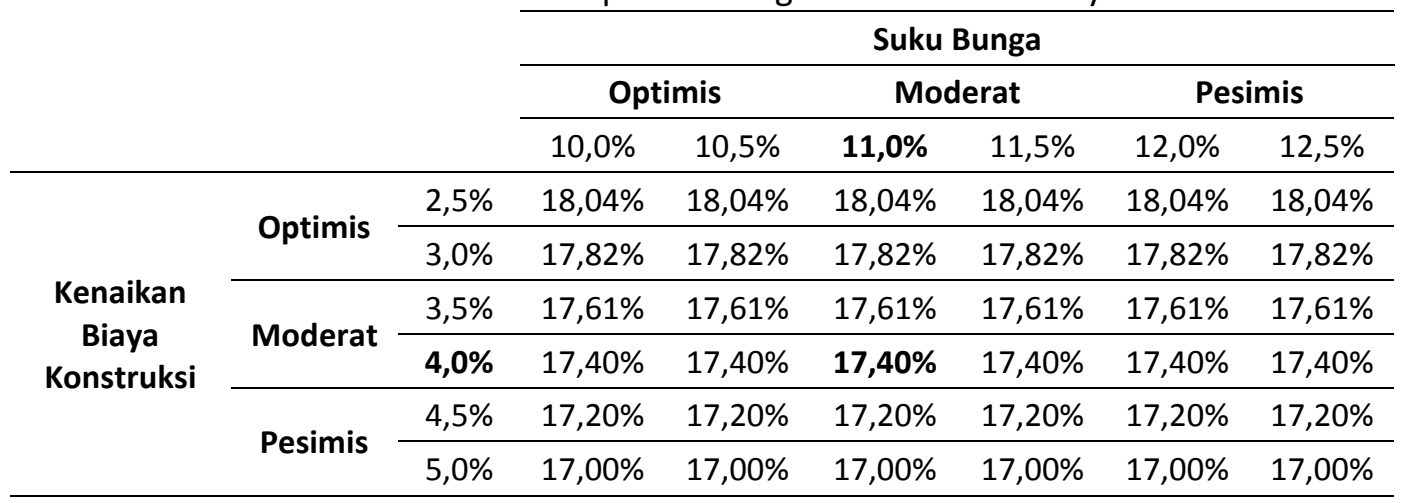

Sumber: Olahan Penulis, 2021

Berdasarkan tabel sensitivitas IRR terhadap suku bunga dan kenaikan biaya konstruksi di atas, dapat diketahui bahwa IRR yang dihasilkan pada cash flow dan sebesar 17,4\% merupakan hasil IRR dengan suku bunga moderat yaitu $11 \%$, dan juga kenaikan biaya konstruksi moderat sebesar $4 \%$.

Untuk suku bunga, terbagi atas 3 skenario dengan kisaran angka 10-12,5\%. Sedangkan untuk besaran 
kenaikan biaya konstruksi berada pada kisaran 2,5-5\% per tahunnya. Berikut merupakan grafik sensitivitas IRR terhadap suku bunga dan kenaikan biaya konstruksi.

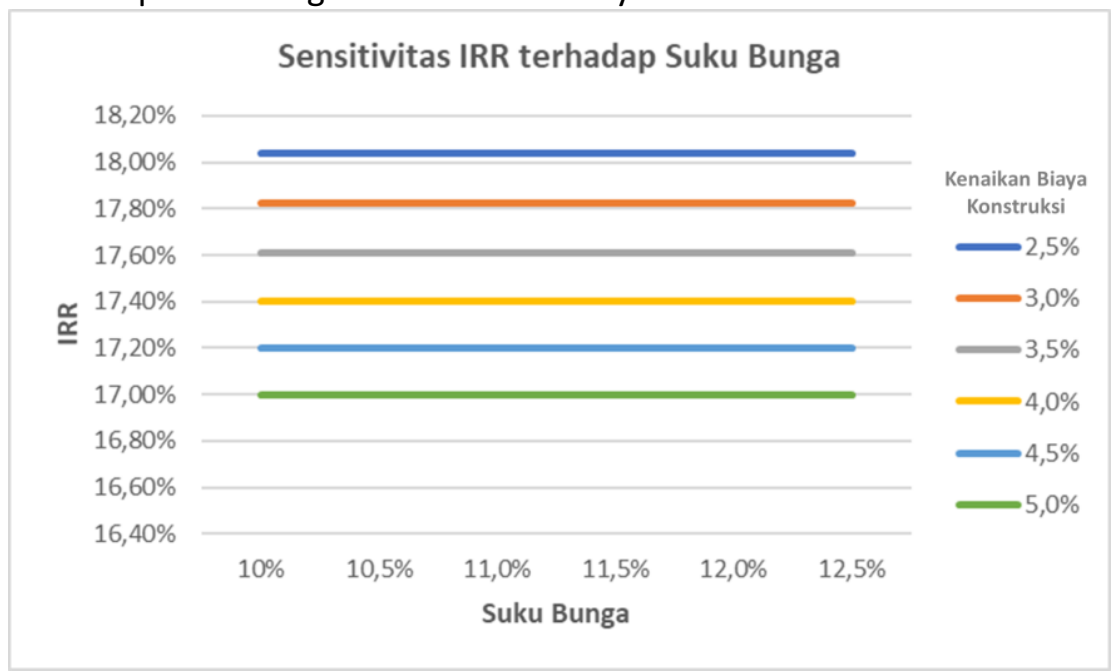

Gambar 3. Grafik Sensitivitas IRR terhadap Suku Bunga Sumber: Olahan Penulis, 2020

Dari grafik sensitivitas IRR terhadap suku bunga di atas, dapat diketahui bahwa tidak ada perbedaan besaran IRR meskipun variabel suku bunga mengalami peningkatan. Hal tersebut disebabkan karena suku bunga merupakan variabel acuan bagi IRR untuk menentukan kelayakan dari investasi terkait.

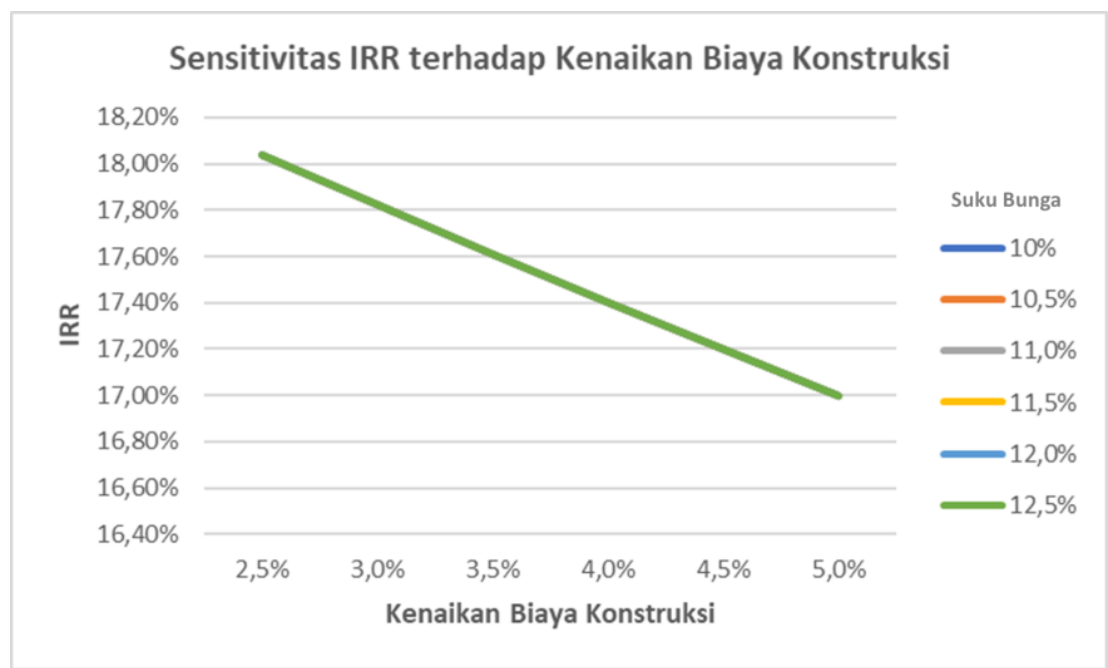

Gambar 4. Grafik Sensitivitas IRR terhadap Kenaikan Biaya Konstruksi (Olahan Penulis, 2021)

Untuk kenaikan biaya konstruksi, dapat terlihat pada grafik di atas bahwa variabel tersebut memiliki pengaruh terhadap IRR. Semakin rendah besaran kenaikan biaya konstruksi, semakin besar IRR yang dihasilkan. Namun, semakin tinggi besaran kenaikan biaya konstruksi, semakin kecil IRR yang dihasilkan.

\section{Sensitivitas NPV terhadap Take-Up Rate dan Kenaikan Harga Jual}

Sensitivitas NPV akan diuji dengan 2 variabel yang berkaitan dengan penerimaan (cash in), yaitu takeup rate dan kenaikan harga jual, dan berikut adalah tabel tersebut.

Tabel 10. Sensitivitas NPV terhadap Take-Up Rate dan Kenaikan Harga Jual 


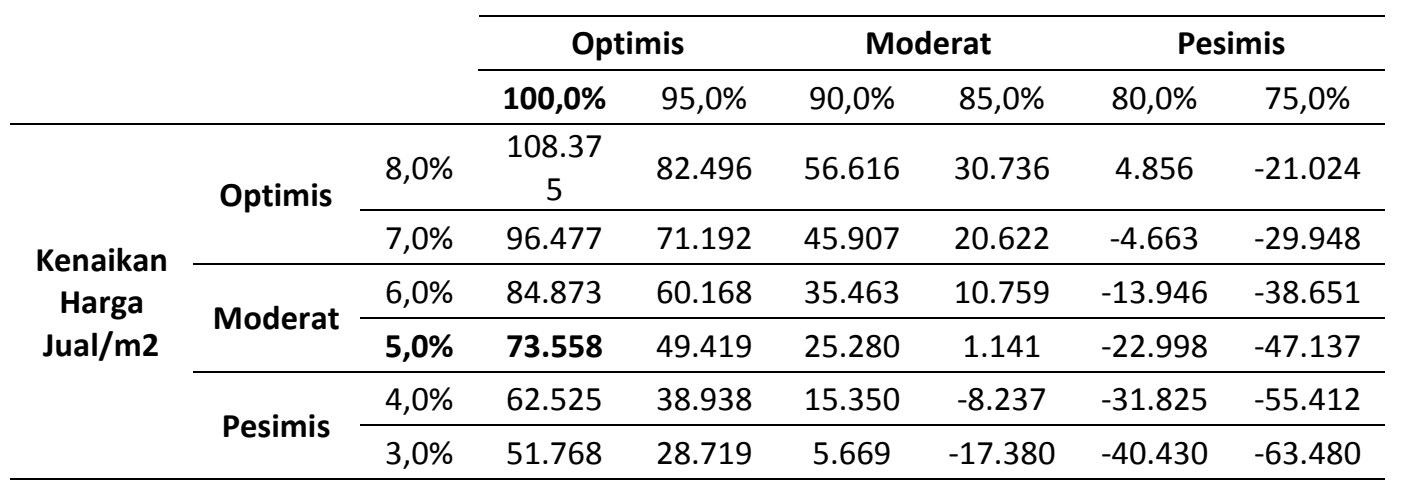

Sumber: Olahan Penulis, 2021

Berdasarkan tabel sensitivitas NPV terhadap take-up rate dan kenaikan harga jual di atas, dapat diketahui bahwa NPV yang dihasilkan pada cash flow dan sebesar Rp 73.558 .000 merupakan hasil NPV dengan take-up rate optimis yaitu $100 \%$, dan juga kenaikan harga jual moderat sebesar $5 \%$ per tahunnya.

Untuk take-up rate, terbagi atas 3 skenario dengan kisaran angka 75-100\%. Sedangkan untuk besaran kenaikan harga jual berada pada kisaran 3-8\% per tahunnya. Berikut merupakan grafik sensitivitas NPV terhadap take-up rate dan kenaikan harga jual.

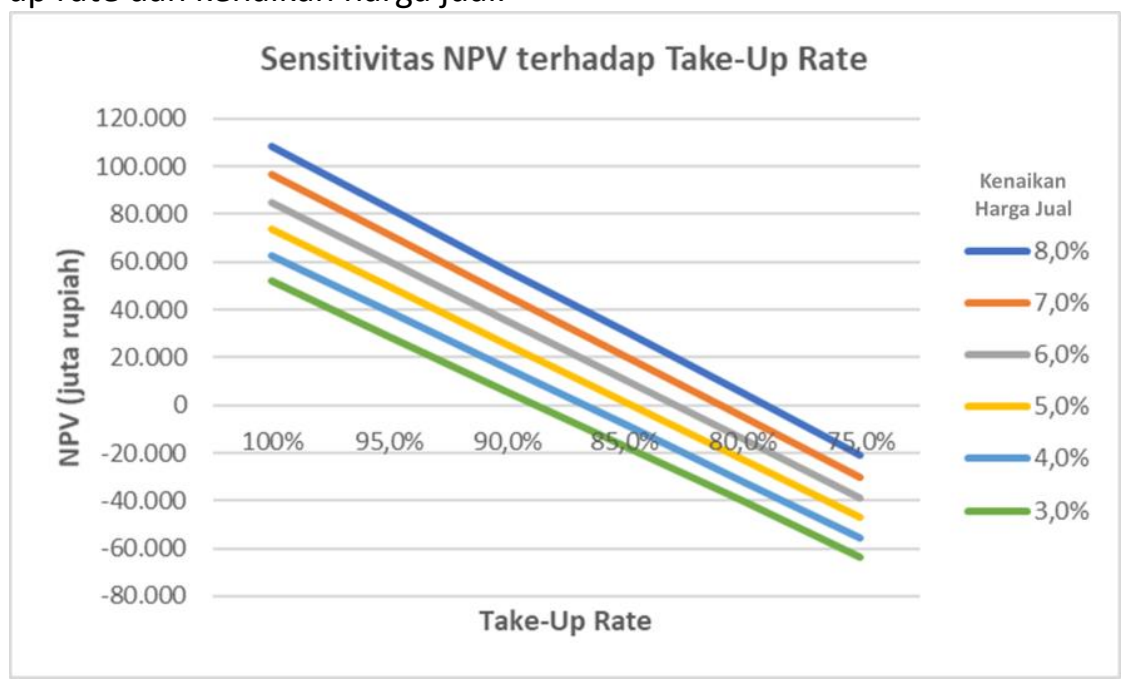

Gambar 9. Grafik Sensitivitas NPV terhadap Take-Up Rate

(Olahan Penulis, 2021)

Berdasarkan grafik sensitivitas NPV terhadap take-up rate di atas, dapat diketahui bahwa variabel tersebut memiliki pengaruh terhadap NPV. Semakin tinggi take-up rate, akan semakin besar NPV yang dihasilkan. Begitu juga sebaliknya, semakin rendah take-up rate, akan semakin kecil NPV yang dihasilkan, bahkan NPV tersebut bisa memiliki angka yang minus dan dinyatakan tidak layak investasinya. 


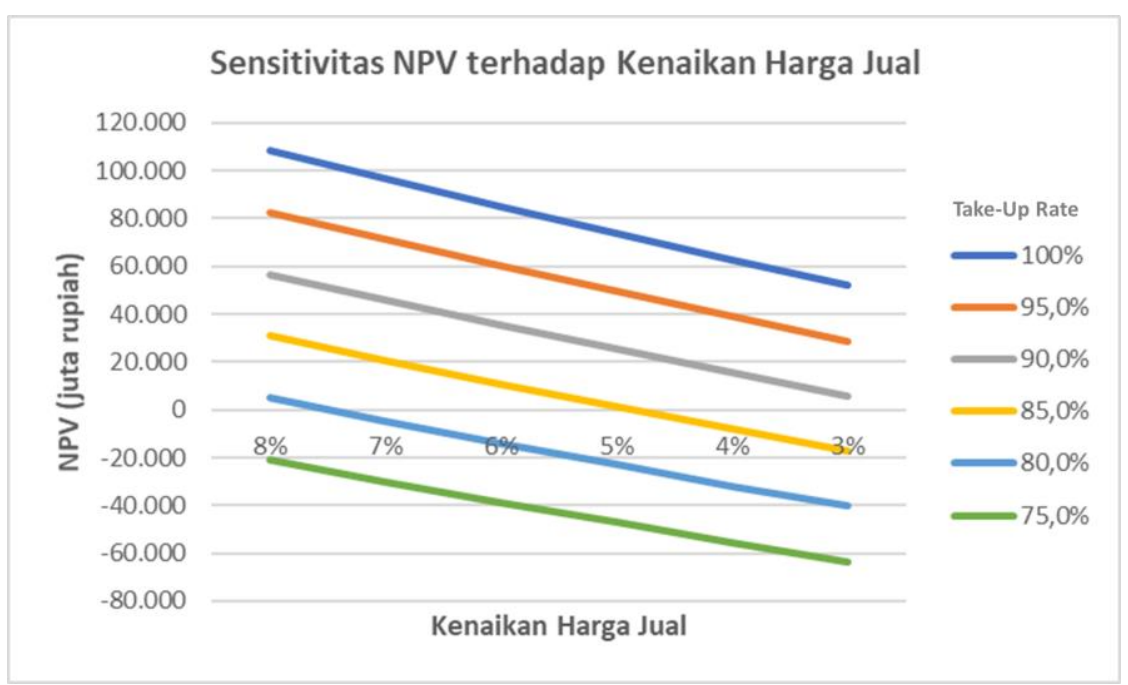

Gambar 10. Grafik Sensitivitas NPV terhadap Kenaikan Harga Jual

(Olahan Penulis, 2021)

Untuk kenaikan harga jual, dapat terlihat pada grafik di atas bahwa variabel tersebut juga memiliki pengaruh terhadap IRR. Semakin tinggi besaran kenaikan harga jual, akan semakin besar IRR yang dihasilkan. Begitu juga sebaliknya, semakin rendah besaran kenaikan harga jual, akan semakin kecil IRR yang dihasilkan, bahkan NPV tersebut bisa memiliki angka yang minus dan dinyatakan tidak layak investasinya.

\section{Regresi IRR dan Variabel Pengembangan}

Analisis regresi ini dilakukan antara IRR dengan masing-masing variabel pengembangan yang telah ditentukan sebelumnya. Analisis tersebut bertujuan untuk mengetahui variabel mana yang memiliki hubungan atau pengaruh paling besar terhadap IRR. Regresi ini dilakukan menggunakan SPSS, dan hasil yang digunakan dari analisis tersebut adalah koefisien korelasi ( $r$ ) dan koefisien determinasi ( $r$ square). Berikut merupakan tabel rangkuman regresi antara IRR dan keempat variabel tersebut.

Tabel 11. Hasil Regresi antara IRR dan Variabel Pengembangan

\begin{tabular}{lcccc} 
& \multicolumn{4}{c}{ IRR } \\
\cline { 2 - 5 } & Suku Bunga & $\begin{array}{c}\text { Kenaikan Biaya } \\
\text { Konstruksi }\end{array}$ & Take-Up Rate & $\begin{array}{c}\text { Kenaikan } \\
\text { Harga Jual }\end{array}$ \\
\hline $\mathbf{R}$ & 0,000 & 0,673 & 0,861 & 0,918 \\
\hline R square & 0,000 & 0,453 & 0,850 & 0,907 \\
\hline
\end{tabular}

Sumber: Olahan Penulis, 2021

Berdasarkan tabel hasil regresi antara IRR dan 4 variabel pengembangan di atas, dapat diketahui bahwa terdapat 3 variabel yang memiliki hubungan yang cukup kuat hingga sangat kuat positif, yaitu kenaikan biaya konstruksi, take-up rate, dan kenaikan harga jual. Selain itu, dapat diketahui juga bahwa variabel kenaikan harga jual memiliki besaran $r$ yang paling besar, yaitu 0,918. Dengan demikian, dapat disimpulkan bahwa variabel tersebut merupakan variabel yang paling berpengaruh terhadap IRR atau salah satu indikator kelayakan investasi pengembangan Cisauk Point.

\section{Regresi NPV dan Variabel Pengembangan}

Analisis regresi ini dilakukan antara NPV dengan masing-masing variabel pengembangan yang telah ditentukan sebelumnya. Analisis tersebut bertujuan untuk mengetahui variabel mana yang memiliki hubungan atau pengaruh paling besar terhadap NPV. Regresi ini dilakukan menggunakan SPSS, dan hasil yang digunakan dari analisis tersebut adalah koefisien korelasi $(r)$ dan koefisien determinasi $(r$ square). Berikut merupakan tabel rangkuman regresi antara NPV dan keempat variabel tersebut. 
Tabel 12. Hasil Regresi antara NPV dan Variabel Pengembangan

\begin{tabular}{lcccc} 
& \multicolumn{4}{c}{ NPV } \\
\cline { 2 - 5 } & $\begin{array}{c}\text { Kenaikan } \\
\text { Biaya Konstruksi }\end{array}$ & Suku Bunga & Take-Up Rate & $\begin{array}{c}\text { Kenaikan } \\
\text { Harga Jual }\end{array}$ \\
\hline $\mathbf{R}$ & 0,682 & 0,728 & 0,884 & 0,933 \\
\hline R square & 0,466 & 0,612 & 0,869 & 0,915 \\
\hline
\end{tabular}

Sumber: Olahan Penulis, 2021

Dari tabel hasil regresi antara NPV dan 4 variabel pengembangan di atas, dapat diketahui bahwa seluruh variabel tersebut memiliki hubungan yang cukup kuat hingga sangat kuat positif, yaitu kenaikan biaya konstruksi, suku bunga, take-up rate, dan kenaikan harga jual. Selain itu, dapat diketahui juga bahwa variabel kenaikan harga jual memiliki besaran $r$ yang paling besar, yaitu 0,933. Dengan demikian, dapat disimpulkan bahwa variabel tersebut merupakan variabel yang paling berpengaruh terhadap NPV atau salah satu indikator kelayakan investasi pengembangan Cisauk Point.

\section{KESIMPULAN DAN SARAN}

\section{Kesimpulan}

Pandemi COVID-19 membawa dampak negatif bagi pengembangan properti, tidak terkecuali pengembangan Cisauk Point. Pengembangan Cisauk Point mengalami beberapa hambatan, baik itu konstruksi maupun penjualan unit Tower Sapphire, yang merupakan tower pertama yang dikembangkan pada Cisauk Point. Hambatan pada tahap konstruksi mengakibatkan penundaan perampungan tower tersebut pada Desember 2021, yang juga menyebabkan pengembangan tower setelahnya tertunda. Pada tahap penjualan unit pun mengalami hambatan akibat Pandemi Covid-19, dimana penjualan unit mengalami perlambatan yang cukup signifikan karena menurunnya daya beli masyarakat terhadap properti di masa Pandemi Covid-19.

Berdasarkan analisis investasi yang sudah dilakukan, dapat dinyatakan bahwa investasi pengembangan Cisauk Point masih layak meski adanya Pandemi COVID-19. Hal tersebut dapat dibuktikan dengan beberapa indikator kelayakan investasi sebagai berikut, IRR sebesar 17,4\%, NPV sebesar Rp 73.558.000.000, PI sebesar 1,13, dan ROI sebesar 56\%.

Variabel-variabel pengembangan yang mempengaruhi sensitivitas pengembalian investasi Cisauk Point antara lain, yaitu suku bunga, kenaikan biaya konstruksi, take-up rate, dan kenaikan harga jual. Keempat variabel tersebut memiliki pengaruh terhadap 2 indikator kelayakan investasi, yaitu IRR dan NPV, kecuali suku bunga dengan IRR yang tidak memiliki hubungan karena suku bunga merupakan variabel yang menjadi acuan dalam menentukan kelayakan investasi.

Variabel yang paling berpengaruh terhadap IRR dan NPV adalah kenaikan harga jual, dikarenakan variabel tersebut memiliki koefisien korelasi ( $r$ ) dan koefisien determinasi ( $r$ square) yang lebih besar jika dibandingkan dengan variabel lainnya.

\section{Saran}

Bagi developer, dapat meningkatkan layanan berbasis teknologi dalam konteks pemasaran, seperti: WhatsApp Blast, peluncuran produk via online melalui aplikasi video, pemilihan unit via online, memberikan informasi proses konstruksi terkini melalui YouTube, iklan di Instagram, survei unit contoh dapat melalui aplikasi Virtual Tour. Selain itu, dapat juga memberikan diskon dan promosi yang menarik, seperti diskon mencapai $\geq 10 \%$, cashback, bonus furniture, gratis barang elektronik dan gadget, pemberian voucher, dll. Dengan demikian, diharapkan penjualan unit dari Apartemen Cisauk Point dapat sold out dalam waktu yang lebih singkat.

Bagi pembeli, berdasarkan analisis pasar makro yang telah dilakukan, saat ini merupakan good timing 
untuk membeli properti terutama untuk kalangan end user. Jika niat dan dananya sudah terkumpul sebaiknya segera dibelikan properti khususnya segmen menengah ke bawah. Hal tersebut disebabkan oleh bunga bank yang sedang bersahabat dan developer pun cenderung tidak menerapkan margin yang besar seperti saat situasi normal. Sehingga jika transaksi dilakukan pada saat ini atau saat Pandemi COVID-19 akan mendapatkan harga yang sangat baik bagi pembeli.

\section{REFERENSI}

Aurora, R. P. (2011). Analisa Teknis dan Finansial Proyek Pembangunan Apartemen Ciputra World Surabaya. Jurnal Insitut Teknologi Sepuluh Nopember Surabaya.

Balkhair, A. A. (2020). COVID-19 Pandemic: A New Chapter in History of Infectious Diseases. Oman Medical Journal.

Blair, V. B. (1988). How to Conduct \& Analyze Real Estate Market and Feasibility Studies. New York: Van Nostrand Reinhold.

Cummings, J. (2008). Real Estate Finance \& Investment Manual. New Jersey: John Wiley \& Sons, Inc.

Fisher, W. B. (2011). Real Estate Finance and Investment. New York: McGraw-Hill Companies.

Graaskamp, J. A. (1972). A Rational Approach to Feasibility Analysis. Chicago: Society of Real Estate Appraisers.

Hestu Prasetya, F. S. (2017). Analisis Teknis dan Finansial Proyek Pembangunan Apartemen UResidence 3 Karawaci, Tangerang Selatan. e-Jurnal Matriks Teknik Sipil, 1-8.

Mathofani, A. (2014). Analisa Kelayakan Finansial Proyek Pembangunan Apartemen The Peak Pekanbaru. Jurnal FTEKNIK Volume 2 No.1.

Mike E. Miles, B. G. (2015). Real Estate Development: Principles and Process. Washington DC: Urban Land Institute.

Park, C. S. (2013). Fundamentals of Engineering Economics . Harlow: Pearson Education Limited.

Paul, S. (1967). Apartments: Their Design and Development. Michigan: Reinhold Publishing Company. Singer, G. T. (2005). The Real Estate Invesment Handbook. New Jersey: John Wiley \& Sons, Inc. 